\title{
ANALISIS FAKTOR-FAKTOR YANG MEMPENGARUHI PRODUKTIVITAS PERKEBUNAN KARET DI KECAMATAN SINGKUT KABUPATEN SAROLANGUN
}

\author{
Simon JB Sirait ${ }^{1}$, Armen Mara ${ }^{2}$, dan Zakky Fathoni ${ }^{3}$ \\ ${ }^{1)}$ Alumni Jurusan Agribisnis Fakultas Pertanian Universitas Jambi \\ ${ }^{2)}$ Staf Pengajar Jurusan Agribisnis Fakultas Pertanian Universitas Jambi \\ Email : batrico_Sirait@yahoo.com
}

ABSTRAK

Penelitian ini bertujuan untuk mengetahui deskripsi, rata-rata produktivitas perkebunan karet serta untuk menganalisis faktor produksi yang meliputi luas lahan, jumlah batang, jumlah tenaga kerja, umur tanaman, jenis bibit, teknik penyadapan dan kondisi kebun di Kecamatan Singkut Kabupaten Sarolangun. Data yang dikumpulkan meliputi data primer dan sekunder. Pemilihan lokasi dilakukan secara purposive dilatar belakangi Kecamatan Singkut merupakan salah satu penghasil karet terbaik di Kabupaten Sarolangun. Walaupun Kecamatan Singkut hanya menyumbang 8.03 \% luas lahan karet dari total luas lahan karet di Kabupaten Sarolangun, namun kecamatan ini mampu memberikan kontribusi produksi sebesar $13.48 \%$. Hal ini berbeda dengan Kecamatan Mandiangin, Kecamatan Bathin VII dan Kecamatan Pauh dengan kontribusi luas lahan berturut-turut sebesar $22.50 \%, 18.91 \%$, dan $18.06 \%$ sedangkan untuk kontribusi produksinya masing-masing sebesar $17.63 \%, 20.05 \%$ dan $16.7 \%$. Salah satu penyebab produktivitas tinggi di kecamatan ini dikarenakan produksinya lebih besar dari luas areal karet yang menghasilkan. Data dianalisis secara deskriptif kuantitatif dan dilanjutkan dengan menggunakan metode CobbDouglas. Dari hasil penelitian diketahui secara bersama-sama faktor tersebut mempengaruhi produktivitas karet, dan faktor tersebut mampu menjelaskan produktivitas karet sebesar 82,3 persen, secara parsial faktor produktivitas yang berpengaruh secara nyata adalah luas lahan, jumlah tenaga kerja, jenis bibit, teknik penyadapan, dan kondisi kebun.

Kata Kunci : Produktivitas, usaha tani, Perkebunan Karet

\section{ANALYSIS OF THE FACTORS AFFECT THE PRODUCTIVITY OF RUBBER PLANTATIONS IN SINGKUT SUB DISRTICT SAROLANGUN REGENCY}

\author{
Simon JB Sirait ${ }^{1}$, Armen Mara ${ }^{2}$, and Zakky Fathoni ${ }^{3}$ \\ ${ }^{1)}$ Alumni of Agribussiness Department Faculty of Agriculture University of Jambi \\ ${ }^{2)}$ Lecturer at the Agribussiness Department Faculty of Agriculture University of Jambi \\ Email : batrico_Sirait@yahoo.com \\ ABSTRACT
}

\begin{abstract}
This research aims to describe the smallholder rubber plantation, to analyze the productivity average of rubber plantations, and to analyze the factors of production that covers land area, number of stems, the amount of labor, age, type of plant seeds, plantation conditions and tapping techniques in Singkut Sub District Sarolangun. The Data that is collected includes the primary and secondary data. Site selection choosen purposively where Singkut Subdistrict is one of the best producers of rubber in Sarolangun. Although the Sub-District of Singkut only contributed for $8.03 \%$ from total area of rubber in Sarolangun Regency, but the district was able to contribute to the production as big as $13,48 \%$. It contrasts with the Mandiangin, Bathin VII, and Pauh sub district that has contributed as big as $22,50 \%, 18.91 \%$, and $18,06 \%$ of total rubber plantation area. Meanwhile, for the production contribution these districts have contributed as big as $17.63 \%, 20,05 \%$ and $16.7 \%$. One of the causes of high productivity in this is due to the production is larger thanproductive area. Data were analyzed by using descriptive quantitative and proceed with Cobb-Douglas method. Based on the result of research is known these factors collectively affect the productivity of the rubber, and these factors able to explain the rubber productivity of 82.3 percent, partially factors that influence in rubber productivity are land area, number of labor, type of seeds, techniques of rubber tapping, and the condition of the plantation.
\end{abstract}




\section{PENDAHULUAN}

Provinsi Jambi adalah salah satu daerah yang struktur perekonomiannya masih bercorak agraris, dimana sebagian besar kegiatan ekonominya masih bertumpu pada sektor pertanian. Hal ini menunjukkan bahwa perekonomian Provinsi Jambi masih didukung penuh oleh sektor pertanian terutama subsektor perkebunan, yang terlihat dari besar kontribusinya terhadap PDRB. Kondisi perkebunan yang ada di Provinsi Jambi hingga saat ini masih didominasi oleh perkebunan rakyat dengan mayoritas komoditi yang menonjol adalah tanaman karet (Dinas Perkebunan Provinsi Jambi, 2011).

Menurut Anggara, A (2008) subsektor perkebunan mempunyai peranan penting dalam pembangunan nasional, terutama dalam meningkatkan kemakmuran dan kesejahteraan rakyat, penerimaan devisa Negara, penyediaan lapangan kerja, perolehan nilai tambah dan daya saing, pemenuhan kebutuhan konsumsi dalam negeri, bahan baku industri dalam negeri serta optimalisasi pengelolaan sumber daya alam secara berkelanjutan.

Karet merupakan komoditi unggulan pada subsektor perkebunan yang terus menjadi perhatian pemerintah untuk dikembangkan dalam upaya meningkatkan pendapatan dan kesejahteraan petani, karena tanaman karet mempengaruhi perekonomian provinsi Jambi dan sebanyak 251.184 KK penduduk di daerah Jambi berkaitan mata pencahariannya dari karet (BPS, 2009). Pada tahun 2006-2011, peningkatan produksi perkebunan karet di Provinsi Jambi meningkat sebesar $12.21 \%$ sedangkan untuk luas lahan dan tenaga kerja masing-masing meningkat sebesar $3.64 \%$ dan $4.38 \%$. Sedangkan untuk peningkatan produktivitas yaitu sebesar $10.37 \%$. Salah satu wilayah di Provinsi Jambi yang banyak mengusahakan komoditas karet adalah Kabupaten Sarolangun dengan produktivitas tertinggi dari semua kabupaten yang ada di Provinsi Jambi yaitu sebesar $944 \mathrm{~kg} / \mathrm{ha} /$ tahun disusul oleh Kabupaten Tanjung Jabung Barat sebesar $917 \mathrm{~kg} / \mathrm{ha} / \mathrm{tahun}$ dan yang terendah adalah Kabupaten Tanjung Jabung Timur dengan produktivitas sebesar $726 \mathrm{~kg} / \mathrm{ha} /$ tahun.

Provinsi Jambi merupakan provinsi dengan luas areal perkebunan karet terluas kedua setelah Provinsi Sumatera Selatan dengan luas areal sebesar $436.160 \mathrm{Ha}$ atau sekitar $14.85 \%$ dari seluruh luas areal perkebunan karet di Indonesia. Namun dalam hal ini, produktivitas karet di Provinsi Jambi tergolong masih sangat rendah dibandingkan dengan provinsi lain sehingga produksinya juga tidak terlalu besar. Provinsi Jambi memiliki produktivitas terendah ketiga dari seluruh provinsi penghasil karet yang ada di Indonesia atau sebesar $849 \mathrm{~kg} / \mathrm{ha} /$ tahun sedangkan untuk produktivitas tertinggi yaitu provinsi Sumatera Barat, Riau dan Kalimantan Tengah mencapai produktivitas sebesar $1000 \mathrm{~kg} / \mathrm{ha} /$ tahun dan untuk provinsi lainnya mendekati produktivitas hampir mencapai $1000 \mathrm{~kg} / \mathrm{ha} /$ tahun.

Kabupaten Sarolangun merupakan salah satu kabupaten penghasil karet terbaik di Provinsi Jambi dengan produktivitas tertinggi sebesar $944 \mathrm{~kg} / \mathrm{ha} / \mathrm{tahun}$. Setiap tahun luas areal, produksi, produktivitas dan jumlah petani perkebunan karet di Kabupaten Sarolangun mengalami peningkatan. Dimana pada periode 2006-2011 peningkatan luas areal, produksi, produktivitas dan jumlah petani berturut-turut meningkat sebesar $1.25 \%, 0.49 \%, 2,73 \%$ dan peningkatan jumlah petani sebesar $5,01 \%$. Dengan bertambahnya produktivitas karet tersebut atau dari $917 \mathrm{~kg} / \mathrm{ha} /$ tahun menjadi 944 $\mathrm{kg} / \mathrm{ha} /$ tahun, secara otomatis juga produksinya akan semakin meningkat.

Salah satu penghasil karet terbaik di Kabupaten Sarolangun adalah Kecamatan Singkut. Walaupun Kecamatan Singkut hanya menyumbang 8.03 \% luas lahan karet dari total luas lahan karet di Kabupaten Sarolangun, namun kecamatan ini mampu memberikan kontribusi produksi sebesar $13.48 \%$. Hal ini berbeda dengan Kecamatan Mandiangin, Kecamatan Bathin VII dan Kecamatan Pauh dengan kontribusi luas lahan berturut-turut sebesar $22.50 \%, 18.91 \%$, dan $18.06 \%$ sedangkan untuk kontribusi 
produksinya masing-masing sebesar $17.63 \%, 20.05 \%$ dan $16.7 \%$. Salah satu penyebab produktivitas tinggi di kecamatan ini dikarenakan produksinya lebih besar dari luas areal karet yang menghasilkan, sedangkan untuk kecamatan lain yang mempunyai luas lahan yang cukup besar, produktivitasnya rendah dikarenakan produksinya lebih kecil daripada luas arealnya.

Gambaran umum yang diperoleh pada saat observasi awal di Kecamatan Singkut Kabupaten Sarolangun adalah sebagai berikut : (1) Kepemilikan lahan pada umumnya adalah milik sendiri, (2) Jenis bibit karet yang dipergunakan oleh masyarakat pada umumnya bibit unggul, (3) teknik penyadapan yang dilakukan masih rendah (belum sesuai anjuran) seperti penyadapan dilakukan dengan dua penyadapan sekaligus dalam satu batang atau dari kiri atas dan kanan atas, (4) jumlah tanaman karet persatuan hektar cukup karena jarak tanam tidak terlalu rapat (dengan jarak tanam $3 \times 4,3 \times 5,3 \times 6$ ), (5) kondisi kebun di Kecamatan Singkut pada umumnya sudah teratur atau kondisi kebun bukan lagi hutan karet, (6) untuk tenaga kerja pada umumnya tenaga kerja dalam keluarga, dan (7) umur tanaman pada umumnya merupakan tanaman yang sudah menghasilkan. Berdasarkan gambaran diatas tersebut dapat diketahui bahwa masih perlu adanya pengembangan usahatani perkebunan karet karena produktivitasnya masih bisa dimaksimalkan.

Adapun tujuan penelitian adalah untuk mengetahui deskripsi, rata-rata produktivitas perkebunan karet serta untuk menganalisis faktor produksi yang meliputi luas lahan, jumlah batang, jumlah tenaga kerja, umur tanaman, jenis bibit, teknik penyadapan dan kondisi kebun di Kecamatan Singkut Kabupaten Sarolangun.

\section{METODE PENELITIAN}

Penelitian ini dilaksanakan di Kecamatan Singkut Kabupaten Sarolangun. Ruang lingkup penelitian ini difokuskan pada faktor-faktor yang mempengaruhi produktivitas karet di Kecamatan Singkut Kabupaten Sarolangun yaitu faktor luas lahan, jumlah waktu kerja, jenis bibit, kondisi kebun, teknik penyadapan, jumlah batang dan umur tanaman karet yang sudah berproduksi. Selanjutnya dipilih 3 desa dalam penelitian ini yaitu Desa Bukit Murau dengan produktivitas tertinggi, Desa Siliwangi dengan produktivitas sedang dan Desa Simpang Nibung dengan produktivitas terendah. Penelitian ini dilaksanakan pada bulan Oktober sampai bulan November 2013.

Menurut Usman (2009), data primer merupakan data yang didapat dari sumber pertama atau sumber asli (langsung dari informan). Data primer diperoleh dengan melakukan wawancara dengan petani secara langsung. Sedangkan, data sekunder merupakan struktur atau historis mengenai variabel-variabel yang telah dikumpulkan dan dihimpun sebelumnya oleh pihak lain. Data sekunder yang diperoleh berasal dari berbagai instansi antara lain Badan Pusat Statistik Provinsi Jambi dan Kabupaten Sarolangun, Dinas Pertanian dan Dinas Perkebunan Provinsi Jambi, Kantor Kecamatan Singkut, Balai Penyuluhan Pertanian, Perikanan dan Kehutanan (BP3K) Kecamatan Singkut. Metode pengumpulan data yang digunakan dalam penelitian ini yaitu, terdiri dari: (1) Interview, yaitu pengumpulan data yang diperoleh dari wawancara dengan mengajukan pertanyaan-pertanyaan berdasarkan daftar pertanyaan (kuisioner) secara langsung dengan petani karet rakyat. (2) Observasi, yaitu dengan cara pengamatan langsung secara sistematis terhadap aktivitas petani karet rakyat. (3) Studi pustaka, yaitu untuk menunjang pengumpulan data di lapangan, diperlukan studi kepustakaan dimana digunakan literatur yang berhubungan dengan judul penelitian. (4) Dokumentasi kegiatan usahatani karet rakyat di daerah penelitian.

Populasi dalam penelitian ini adalah seluruh petani karet yang ada di Desa Bukit Murau, Desa Siliwangi dan Desa Simpang Nibung di Kecamatan Singkut Kabupaten 
Sarolangun. Teknik pengambilan sampel yang digunakan dalam penelitian ini dengan menggunakan teknik Non Probability Sampling yaitu dengan sampling Purposive atau dimaksud dengan penentuan sampel dengan pertimbangan tertentu. Dalam hal ini, pertimbangan yang diambil oleh peneliti yaitu mengambil populasi di Kecamatan Singkut karena di kecamatan ini memiliki produktivitas karet yang tertinggi. Selanjutnya untuk menentukan petani sampel dilakukan secara acak sederhana atau simple random sampling.

Jumlah sampel dalam penelitian ini ditentukan dengan menggunakan rumus dari Slovin dalam Riduwan (2007) sebagai berikut :

$$
\begin{aligned}
\mathrm{n}=\frac{N}{N d^{2}+1} \quad \text { dimana : } \mathrm{n} & =\text { Jumlah sampel } \\
\mathrm{N} & =\text { Jumlah populasi petani karet } \\
\mathrm{d}^{2} & =\text { Presisi (ditetapkan 10\%) }
\end{aligned}
$$

Berikut adalah rincian jumlah sampel pada setiap desa dapat dilihat pada tabel :

Tabel 1. Rincian Jumlah Petani Populasi dan Sampel per Desa di Daerah Penelitian.

\begin{tabular}{ccc}
\hline Desa & Jumlah Populasi (KK) & Jumlah Sampel \\
\hline Desa Bukit Murau & 935 & 51 \\
Desa Siliwangi & 392 & 22 \\
Desa Simpang Nibung & 386 & 21 \\
\hline Jumlah & $\mathbf{1 7 1 3}$ & $\mathbf{9 4}$
\end{tabular}

Sumber : Hasil Perhitungan Data Sekunder

Untuk mengetahui faktor-faktor yang mempengaruhi produktivitas karet rakyat digunakan analisis dengan metode Cobb-Douglas yang melibatkan dua variabel yaitu variabel dependent yang menjelaskan $Y$ dan variabel independent yang menjelaskan $X$. berikut ini merupakan bentuk dan persamaan Cobb-Douglass (Gujarati, 2003) :

$\log Y=\log \alpha+b 1 \log \times 1+b 2 \log \times 2+b 3 \log \times 3+b 4 \log \times 4+b 5 D 1+b 6 D 2+b 7 D 3+\mu$ dimana :

$\mathrm{Y}=$ Produktivitas Karet $(\mathrm{kg} / \mathrm{ha} /$ tahun)

$\mathrm{X} 1$ = Luas Lahan (ha)

$\mathrm{X} 2$ = Jumlah Batang

X3 = Jumlah Tenaga Kerja

X4 = Umur Tanaman

D1 = Jenis Bibit

D2 = Teknik Penyadapan

D3 = Kondisi Kebun

$A=$ Konstanta

$\beta_{1}, \beta_{2}, \beta_{3}, \beta_{4}, \beta_{5}, \beta_{6,} \beta_{7}=$ Koefisien Regresi

$\mu=$ Kesalahan Pengganggu

Dengan menggunakan metode Ordinary Least Square (OLS), dari analisis regresi linear akan diperoleh koefisien regresi pada masing masing variabel independen dan juga berapa besar hubungan dari faktor-faktor yang mempengaruhi tersebut secara bersama-sama mempengaruhi produksi karet.

Dalam Uji Kesesuaian (Test Goodness of Fit), estimasi terhadap model dilakukan dengan menggunakan metode yang tersedia pada program statistik SPSS 16 . Koefisien yang dihasilkan dapat dilihat pada output regresi berdasarkan data yang dianalisis untuk kemudian diinterpretasikan serta dilihat signifikansi tiap-tiap variabel yang diteliti.

a. $R^{2}$ (koefisien determinasi) bertujuan untuk mengetahui kekuatan variabel bebas (independent variable) menjelaskan variabel terikat (dependen variable)

b. Uji serempak (F-test), dimaksudkan untuk mengetahui signifikansi statistik koefisien regresi secara serempak. Jika $F_{\text {hit }}>F_{\text {tabel, }}$ maka $H_{0}$ ditolak dan $H_{1}$ diterima 
c. Uji parsial (t-test), dimaksudkan untuk mengetahui signifikansi statistik koefisien regresi secara parsial. Jika $\mathrm{t}_{\text {hit }}>\mathrm{t}_{\text {tabel, }}$ maka $\mathrm{H}_{0}$ ditolak dan $\mathrm{H}_{1}$ diterima.

Analisis data menggunakan program SPSS versi 16.0. Selain kriteria statistik, juga

diperhatikan uji asumsi klasik (uji normalitas, multikolinieritas, heterokedastisitas, dan autokorelasi).

\section{HASIL DAN PEMBAHASAN}

\section{Karakakteristik Petani Responden}

Petani responden yang diambil dalam penelitian ini adalah sebanyak 94 orang, yang terdiri dari 51 orang dari Desa Bukit Murau, 22 orang dari Desa Siliwangi dan 21 orang dari Desa Simpang Nibung dengan persentase umur terbesar 45-50 tahun, tingkat pendidikan lulusan Sekolah Dasar (SD), jumlah tanggungan keluarga sebanyak 4-5 orang dan rata-rata pengalaman berusahatani sebesar 11-16 tahun. Selain itu deskripsi perkebunan karet di daerah penelitian diketahui bahwa rata-rata luas lahan milik petani dengan persentase terbesar yaitu 0,5-2 hektar, untuk rata-rata penggunaan jenis bibit dengan persentase terbesar adalah penggunaan jenis bibit unggul PB 260 dan GT, ratarata jumlah batang dalam satuan hektar dengan persentase terbesar berkisar pada 425500 batang, rata-rata kondisi kebun dengan persentase terbesar adalah kondisi kebun yang teratur/bersih, selain itu rata-rata untuk teknik penyadapan dengan persentase terbesar adalah teknik penyadapan yang sesuai anjuran (penyadapan dengan satu garis melintang), dan rata-rata untuk jumlah hari orang kerja dengan persentase terbesar berada pada selang 978 - 1183 HOK serta untuk rata-rata umur tanaman dengan persentase terbesar yaitu berada pada selang 24,5 - 28 tahun.

\section{Pengujian Model Analisis Faktor yang Mempengaruhi Produktivitas Karet Rakyat}

Dalam penelitian ini digunakan model fungsi produksi Cobb-Douglas dengan metode Ordinary Least Square (OLS) dalam menentukan faktor-faktor yang mempengaruhi produktivitas perkebunan karet rakyat. Adapun variabel bebasnya meliputi : luas lahan, jenis bibit, teknik penyadapan, jumlah batang, kondisi kebun, jumlah tenaga kerja, dan umur tanaman serta variabel terikat adalah produktivitas perkebunan tanaman karet yang ada di Kecamatan Singkut Kabupaten Sarolangun. Dalam pengujian ini diharapkan memenuhi bebas untuk semua asumsi yang disyaratkan. Diantaranya adalah asumsi multikolinieritas, autokorelasi, heteroskedastisitas dan normalitas. Dengan terpenuhinya asumsi-asumsi tersebut, maka akan menghasilkan variabel penduga terbaik yang tidak bias atau disebut BLUE (best linear unbiased estimator). Sebaliknya, jika terdapat salah satu asumsi dalam model Cobb-Douglas yang tidak dapat dipenuhi oleh fungsi yang diperoleh, maka kebenaran pendugaan model atau pengujian hipotesis untuk pengembalian keputusan menjadi diragukan.

Uji Multikolinearitas bertujuan untuk mengetahui apakah tiap-tiap variabel independen saling berhubungan secara linear, apabila sebagian atau seluruh variabel independen berkorelasi kuat berarti terjadi multikolinearitas (Gujarati, 2006). Multikolinearitas ini menyebabkan kesulitan untuk memisahkan pengaruh masingmasing variabel independen terhadap variabel dependen. Gejala multikolinearitas dapat dilihat dari nilai Variable Inlation Factor (VIF). Apabila angka VIF ada yang melebihi 10 atau nilai tolerance kurang dari 0,1 berarti terjadi multikolinearitas. Setelah dilakukan uji multikolinearitas pada variabel-variabel independen dengan pengukuran terhadap VIF hasilnya menunjukkan bahwa semua variabel independen pada semua model yang diajukan bebas dari multikolinearitas atau tidak ada multikolinearitas antar variabel 
independen dalam model. Hal ini ditunjukkan dengan nilai VIF yang berada dibawah 10 dan nilai tolerance lebih dari 0,1 serta diperkuat dengan nilai significance (2-tailed) pada tampilan matrik korelasi Pair-wise Correlation antar variabel independen.

Untuk mengetahui tidak adanya multikolinearitas yang sempurna antara variabel independen pada model persamaan Cobb-Douglas dapat dilihat dari nilai VIF (variance inflation factor) yang dihasilkan oleh masing-masing variabel independen pada model yang dibangun (dilihat dengan nilai) atau dengan melihat dengan nilai Partial Correlation. Jika variabel independen pada model persamaan memiliki nilai VIF sama atau dibawah sepuluh, dapat disimpulkan bahwa model dugaan menunjukkan gejala multikolineritas tidak terdeteksi. Dari hasil penelitian diperoleh nilai VIF untuk masingmasing variabel adalah dibawah nilai sepuluh (kisaran antara 1,240 hingga 2,241) sedangkan untuk nilai tolerance lebih dari 0,1 (berkisar antara 0,446 hingga 0,807) serta diperkuat dengan nilai significance (2-tailed) pada tampilan matriks korelasi pairwise correlations antar variabel independen. Terlihat juga dari luaran SPSS nilai $\mathrm{R}^{2}$ cukup tinggi sebesar $82,3 \%$ sedangkan kebanyakan variabel independen memiliki nilai dan statistik pada taraf nyata $5 \%(\alpha=0,05)$. Oleh karena $R^{2}$ tinggi dan kebanyakan variabelvariabel independennya signifikan, maka tidak ada indikasi terjadi multikolinearitas antar variabel independen, nilai significance (2-tailed) $>0,05$. Jadi dapat disimpulkan bahwa variabel independen bebas dari masalah multikolinearitas.

Tahapan lain dalam pengujian asumsi klasik adalah menilai gejala autokorelasi. Menurut Ghozali (2005) dalam Wijaya (2012) pengujian autokorelasi dimaksudkan untuk menilai serial korelasi antar masing-masing tingkat kesalahan pengganggu pada masing-masing periode observasi. Kriteria pengujian autokorelasi yang digunakan didalam model penelitian ini adalah $-2<\mathrm{dw}<2$. Berdasarkan hasil pengujian data yang telah dilakukan terlihat dalam pengujian nilai Durbin-Watson (DW) yaitu sebesar 1,830. Maka hasil yang diperoleh berada dalam dua kuadran yaitu $-2<1,830<2$ dan oleh sebab itu dapat disimpulkan didalam data penelitian ini tidak ditemukan gejala autokorelasi yang serius baik yang bernilai positif maupun negatif.

Sedangkan untuk mendeteksi masalah heteroskedastisitas dapat digunakan dengan uji grafik dan uji Spearman's rho. Uji grafik yaitu jika titik variance menyebar secara tidak merata diatas maupun dibawah titik 0 dengan tidak membentuk sebuah pola yang jelas maka gejala heteroskedastisitas tidak terdeteksi. Sedangkan uji Spearman's rho yaitu dengan mengkorelasikan nilai residual (Unstandarized Residual) dengan masing-masing variabel independen. Jika signifikansi korelasi kurang dari 0,05 maka pada model regresi terjadi masalah heteroskedastisitas dan sebaliknya (Priyatno, 2004). Berdasarkan hasil penelitian diperoleh nilai $p$-value masing-masing variabel independen lebih besar dari nilai $\alpha$ sebesar $5 \%(\alpha>0,05)$ yang berarti tidak signifikan dan tidak terjadi heteroskedastisitas.

\section{Analisis Faktor-faktor yang Mempengaruhi Produktivitas Perkebunan Karet di Kecamatan Singkut}

Analisis faktor yang mempengaruhi produktivitas perkebunan karet rakyat menggunakan analisis dengan metode Cobb-Douglas. Adapun faktor-faktor yang mempengaruhi produktivitas perkebunan karet rakyat diantaranya adalah luas lahan (X1), jumlah batang (X2), jumlah tenaga kerja (X3), umur tanaman (X4), jenis bibit (D1), kondisi kebun (D2), dan teknik penyadapan (D3). Ketepatan model yang diuji dengan menggunakan uji statistik, yaitu uji $t$-hitung, uji F-hitung dan koefisien determinasi yang disesuaikan dengan $R-s q$ ( $a d j)$. 
Tabel 2. Hasil Analisis Dengan Metode Cobb-Douglas Faktor yang Mempengaruhi Produktivitas Karet Rakyat di Daerah Penelitian

\begin{tabular}{llllll}
\hline No & Variabel & Koefisien & T-hit & $\begin{array}{l}\text { P-Value } \\
\text { (Sig/2) }\end{array}$ & VIF \\
\hline 1 & Konstanta & 2,855 & 4,351 & 0,000 & \\
2 & Luas Lahan & $-1,029$ & $-17,501$ & 0,000 & 1,420 \\
3 & Jumlah Batang & $-0,114$ & $-0,512$ & 0,610 & 1,595 \\
4 & Jumlah Tenaga Kerja & 0,300 & 4,292 & 0,000 & 1,241 \\
5 & Umur Tanaman & $-0,064$ & $-0,695$ & 0,489 & 1,475 \\
6 & Jenis Bibit & $-0,100$ & $-2,156$ & 0,034 & 2,241 \\
7 & Teknik Penyadapan & 0,096 & 2,553 & 0,012 & 1,240 \\
8 & Kondisi Kebun & 0,130 & 3,162 & 0,002 & 2,174 \\
\hline
\end{tabular}

$\mathrm{R}^{2}=82,3 \% \quad \mathrm{R}$-sq(adj) $=80,8 \%$

$\mathrm{F}_{\text {hit }}=57,029 \quad$ P-value $=0,000$

Sumber : Hasil Olahan Data Primer 2013

Berdasarkan hasil analisis dengan metode Cobb-Douglas terhadap faktor yang mempengaruhi produktivitas perkebunan karet di Kecamatan Singkut diperoleh persamaan sebagai berikut :

$\log Y=\log 2,855-1,029 \log X 1-0,114 \log X 2+0,300 \log X 3-0,064 \log X 4-0,100$ $D 1+0,096 D 2+0,130 D 3+e$

Hasil persamaan dengan metode Cobb-Douglas analisis faktor yang mempengaruhi produktivitas perkebunan karet rakyat terangkum dalam tabel 2. Hasil analisis yang diperoleh menunjukkan nilai koefisien determinasi $R^{2}$ (adj) sebesar 82,3 persen yang menunjukkan bahwa variabel-variabel independen (terdiri dari luas lahan, jumlah batang, jumlah tenaga kerja, umur tanaman, jenis bibit, teknik penyadapan, serta kondisi kebun) dalam model mampu menjelaskan sebanyak 82,3 persen perubahan yang terjadi pada produktivitas karet rakyat di daerah penelitian, sedangkan sisanya sebesar 17,6 persen diterangkan oleh faktor lain diluar model.

Pengujian secara simultan digunakan untuk melihat bagaimana variabel independen secara bersama-sama atau simultan mempengaruhi variabel dependen. Pengujian ini dilakukan dengan menggunakan uji $F$ pada taraf nyata 5 persen $(\alpha=0,05)$. Analisis varian menunjukkan bahwa bersama-sama semua variabel $\mathrm{X}$ menunjukkan pengaruh yang sangat berarti terhadap faktor-faktor yang mempengaruhi produktivitas karet rakyat. Hal ini dapat dilihat dengan nilai F-hitung $=57,029$ lebih besar dari nilai Ftabel yaitu sebesar 2,20. Selain itu diketahui nilai F-hitung yang dihasilkan dari hasil analisis persamaan model Cobb-Douglas tersebut adalah 57,029 dengan nilai $p$-value sebesar 0,000. Hal tersebut menunjukkan bahwa semua variabel independen secara bersama-sama berpengaruh terhadap variabel dependen.

Pengujian secara parsial atau uji $t$ digunakan untuk menguji apakah hipotesis yang diajukan dalam penelitian ini diterima atau ditolak dengan mengetahui apakah variabel independen secara individual mempengaruhi variabel dependen. Dalam hal ini dengan memperhatikan nilai t-hitung dapat mengetahui signifikansi antara variabel independen secara terpisah (parsial) terhadap variabel dependen pada taraf nyata 5 persen $(\alpha=0,05)$. Apabila variabel independen signifikan terhadap variabel dependen maka terdapat pengaruh antara vaiabel independen terhadap variabel dependen. Dan sebaliknya apabila tidak signifikan maka tidak terdapat pengaruh nyata antara variabel independen terhadap variabel dependen. Hasil pengujian secara parsial ( $u j i$ t ) dapat dilihat pada tabel dibawah : 
Tabel 3. Pengujian Koefisien Regresi Parsial (Uji t)

\begin{tabular}{lcccc}
\hline Variabel Independen & Koefisien & t-hitung & t-tabel & Kesimpulan \\
\hline Luas Lahan (X1) & $-1,029$ & $-17,501$ & 1,988 & Signifikan \\
Jumlah Batang (X2) & $-0,114$ & $-0,512$ & 1,988 & Tidak Signifikan \\
Jumlah Tenaga Kerja (X3) & 0,300 & 4,292 & 1,988 & Signifikan \\
Umur Tanaman & $-0,064$ & $-0,695$ & 1,988 & Tidak Signifikan \\
Jenis Bibit (D1) & $-0,100$ & $-2,156$ & 1,988 & Signifikan \\
Teknik Penyadapan (D2) & 0,096 & 2,553 & 1,988 & Signifikan \\
Kondisi Kebun (D3) & 0,130 & 3,162 & 1,988 & Signifikan \\
\hline
\end{tabular}

Sumber : Hasil Olahan Data Primer 2013

Dari hasil uji $t$ diatas, dengan membandingkan nilai t-hitung dan $t$-tabel kita dapat mengetahui variabel independen tersebut berpengaruh atau tidak berpengaruh nyata terhadap variabel dependen (produktivitas).

Berdasarkan analisis dengan metode Cobb-Douglas, didapat bahwa nilai sig. untuk luas lahan sadapan (X1) sebesar 0,000 (tabel 2) lebih rendah dibandingkan dengan nilai $\alpha=(0,05)$, dan diketahui bahwa t-hitung lebih besar dari t-tabel $(17,501>$ 1,988). Hal ini menunjukkan bahwa variabel dugaan yakni luas lahan sadapan terbukti secara signifikan mempunyai pengaruh yang nyata terhadap produktivitas perkebunan karet di Kecamatan Singkut. Hasil ini sependapat dengan Soekartawi (1989), Luas lahan pertanian akan mempengaruhi skala usaha, dan skala usaha ini pada akhirnya akan mempengaruhi efisien atau tidaknya suatu usaha pertanian. Seringkali dijumpai, makin luas lahan yang dipakai akan semakin tidak efisien lahan tersebut. Hal ini dapat diakibatkan akan melemahnya pengawasan terhadap penggunaan factor produksi seperti bibit, tenaga kerja, pupuk, dan sebagainya.

Tanda estimasi yang dimiliki oleh variabel luas lahan sadapan bernilai negatif. Hal ini menjelaskan bahwa dengan bertambahnya luas lahan akan mempengaruhi penurunan produktivitas karet atau sebaliknya. Dengan bertambahnya luas lahan akan berimplikasi pada penurunan produktivitas karet, dimana luas lahan sadapan yang besar akan menyebabkan petani kurang memperhatikan pemeliharaan atau perawatan karet tersebut. Selain itu apabila luas lahan besar maka dalam penyadapan memakan waktu lebih lama sehingga sebagian kebun karet disadap pada siang hari. Kondisi tersebut dapat menurunkan produktivitas karena penyadapan yang baik itu dilakukan pada subuh atau pagi hari. Elastisitas luas lahan terhadap produktivitas karet dapat dikatakann inelastis, yaitu sebesar 1,029. Artinya apabila luas lahan ditambah sebesar satu persen (1\%), maka produktivitas karet akan menurun sebesar 1,029 persen, dengan syarat cateris paribus.

Berdasarkan analisis dengan metode Cobb-Douglas, didapat bahwa nilai sig. untuk jumlah batang (X2) sebesar 0,610 (tabel 2) lebih besar dibandingkan dengan nilai $\alpha=(0,05)$, dan diketahui bahwa t-hitung lebih kecil dari t-tabel $(0,512<1,988)$. Hal ini menunjukkan bahwa variabel dugaan yakni jumlah batang berpengaruh negatif tetapi tidak signifikan mempengaruhi produktivitas perkebunan karet di Kecamatan Singkut. Hasil ini sependapat dengan Damanik (2010) yang menyatakan produktivitas satuan luas dipengaruhi oleh jarak tanam dan kerapatan tanaman disamping faktor-faktor yang lainya. Jarak yang lebih sempit akan berdampak negatif dengan beberapa kelemahannya. Beberapa kerusakan yang akan terjadi akibat jarak yang lebih sempit adalah kerusakan mahkota tajuk oleh angin, kematian pohon karena penyakit menjadi lebih tinggi, tercapainya lilit batang sadap lebih lambat dan hasil getahnya akan berkurang. Maka dewasa ini kepadatan kerapatan pohon setiap hektarnya tidak 
melebihi dari jumlah 400 sampai dengan 500 pohon. Hal itu berarti jarak tanamnya perhektar adalah $7 \times 3 \mathrm{~m}, 7,14 \times 3,33 \mathrm{~m}$ atau $8 \times 2,5 \mathrm{~m}$.

Tanda estimasi yang dimiliki oleh variabel jumlah batang bernilai negatif. Hal ini menjelaskan bahwa dengan semakin banyak jumlah batang dalam satuan hektar maka akan mempengaruhi penurunan produktivitas karet atau sebaliknya. Dengan bertambahnya jumlah batang akan berimplikasi pada penurunan produktivitas karet, dimana kerapatan batang tanaman karet dalam lahan akan mengakibatkan kekurangan cahaya matahari sampai ke permukaan tanah yang berpengaruh pada pertumbuhan karet menjadi tidak normal serta akan mengurangi kandungan unsur hara dalam tanah. Jumlah batang yang sesuai anjuran dengan jarak tanam $4 \mathrm{~m} \times 5 \mathrm{~m}$ berkisar antara 400500 batang per hektar dan apabila jumlah batang ditambah lebih banyak lagi maka hal tersebut dapat mengurangi produktivitas karet. Elastisitas jumlah batang terhadap produktivitas karet dapat dikatakan inelastis, yaitu sebesar 0,114 . Artinya apabila jumlah batang per satuan hektar ditambah sebesar satu persen (1\%), maka produktivitas karet akan menurun sebesar 0,114 persen, dengan syarat cateris paribus.

Berdasarkan analisis dengan metode Cobb-Douglas, didapat bahwa nilai sig. untuk jumlah tenaga kerja (X3) sebesar 0,000 (tabel 2) lebih rendah dibandingkan dengan nilai $\alpha=(0,05)$, dan diketahui bahwa t-hitung lebih besar dari t-tabel $(4,292>$ 1,988). Hal ini menunjukkan bahwa variabel dugaan yakni jumlah tenaga kerja terbukti secara signifikan mempunyai pengaruh yang nyata terhadap produktivitas perkebunan karet di Kecamatan Singkut. Hasil penelitian ini serupa dengan penelitian Polman (2000) yang menganalisis bahwa jumlah tenaga kerja nyata mempengaruhi produksi karet dan mempunyai hubungan yang positif dengan produksi karet. Kegiatan yang dilakukan tenaga kerja disini berupa pembukaan lahan, penanaman, pemeliharaan, sampai pada tahap pemanenan.

Tanda estimasi yang dimiliki oleh variabel luas lahan sadapan bernilai positif. Hal ini menjelaskan bahwa dengan bertambahnya jumlah tenaga kerja akan meningkatkan produktivitas karet atau sebaliknya. Elastisitas jumlah tenaga kerja terhadap produktivitas karet dapat dikatakan inelastis, yaitu sebesar 0,300. Artinya apabila jumlah tenaga kerja ditambah sebesar satu persen (1\%), maka akan meningkatkan produktivitas karet sebesar 0,300 persen, dengan syarat cateris paribus.

Berdasarkan analisis dengan metode Cobb-Douglas, didapat bahwa nilai sig. untuk umur tanaman (X4) sebesar 0,489 (tabel 2) lebih besar dibandingkan dengan nilai $\alpha=(0,05)$, dan diketahui bahwa t-hitung lebih kecil dari t-tabel $(0,695<1,988)$. Hal ini menunjukkan bahwa variabel dugaan yakni umur tanaman berpengaruh negatif tetapi tidak signifikan mempengaruhi produktivitas perkebunan karet di Kecamatan Singkut. Hasil penelitian ini serupa dengan penelitian Polman (2000) yang menganalisis bahwa umur tanaman tidak nyata mempengaruhi produksi karet dan mempunyai hubungan yang negatif dengan produksi karet.

Tanda estimasi yang dimiliki oleh variabel umur tanaman bernilai negatif. Hal ini menjelaskan bahwa dengan bertambahnya umur tanaman akan penurunan produktivitas karet atau sebaliknya. Elastisitas umur tanaman terhadap produktivitas karet dapat dikatakan inelastis, yaitu sebesar 0,064. Artinya apabila umur tanaman bertambah sebesar satu persen (1\%), maka akan meningkatkan produktivitas karet sebesar 0,064 persen, dengan syarat cateris paribus.

Jenis bibit merupakan salah satu faktor terpenting dalam usahatani. Variabel jenis bibit merupakan variabel dummy dalam model penelitian ini. Variabel Dummy merupakan variabel yang bersifat kualitatif atau berskala nominal. Cara pemberian kode dummy umumnya menggunakan kategori yang dinyatakan dengan angka 1 dan 0 . Untuk Variabel jenis bibit dalam penelitian ini adalah bernilai 1 untuk jenis bibit unggul/okulasi dan bernilai 0 untuk jenis bibit non unggul/karet alam. 
Berdasarkan analisis dengan metode Cobb-Douglas, didapat bahwa nilai sig. untuk jenis bibit (D1) sebesar 0,034 (tabel 2) lebih kecil dibandingkan dengan nilai $\alpha=$ $(0,05)$, dan diketahui bahwa t-hitung lebih besar dari t-tabel $(2,156>1,988)$. Hal ini menunjukkan bahwa variabel dugaan yakni jenis bibit terbukti secara signifikan mempengaruhi produktivitas perkebunan karet di Kecamatan Singkut. Hasil ini sependapat dengan Tim Penulis PS (2012) menyatakan usaha peningkatan produktivitas tanaman karet baik pada tingkat perusahaan swasta maupun secara nasional, harus dilaksanakan dengan menanam klon-klon unggulan terbaru pada saat penanaman baru ataupun pada saat peremajaan. Dilanjutkan dengan pendapat Soekartawi (1989) dalam pengelolaan sumberdaya produksi, salah satu aspek yang paling penting dalam intensifikasi sumber daya pertanian adalah aspek varietas bibit tanaman. Selain itu juga lemahnya perawatan akan jenis bibit yang unggul akan mengakibatkan efisiensi dari hasil bibit tersebut akan menurun.

Tanda estimasi yang dimiliki oleh variabel jenis bibit bernilai negatif. Hal ini menjelaskan bahwa dengan bertambahnya bibit sesuai anjuran akan menurunkan produktivitas karet atau sebaliknya. Dari penelitian juga diperoleh hasil dengan dikombinasikannya jenis bibit dengan variabel dummy yang lain terbukti bahwa jenis bibit menjadi berpengaruh negatif, artinya apabila kondisi kebun tidak terawat dan teknik penyadapan yang tidak sesuai anjuran maka jenis bibit unggul dapat menurunkan produktivitas. Elastisitas variabel jenis bibit terhadap produktivitas karet dapat dikatakan inelastis, yaitu sebesar 0,100. Artinya apabila jenis bibit sesuai anjuran bertambah sebesar satu persen (1\%), maka akan menurunkan produktivitas karet sebesar 0,100 persen, dengan syarat cateris paribus.

Berdasarkan analisis dengan metode Cobb-Douglas, didapat bahwa nilai sig. untuk teknik penyadapan (D2) sebesar 0,012 (tabel 2) lebih kecil dibandingkan dengan nilai $\alpha=(0,05)$, dan diketahui bahwa t-hitung lebih besar dari t-tabel $(2,553>1,988)$. Hal ini menunjukkan bahwa variabel dugaan yakni teknik penyadapan terbukti secara signifikan mempengaruhi produktivitas perkebunan karet di Kecamatan Singkut. Hasil penelitian ini sependapat dengan Damanik (2010) yang menyatakan faktor penyadapan merupakan salah satu kegiatan pokok dari pengusahaan tanaman karet. Oleh sebab itu penyadapan harus dilakukan dengan hati-hati agar tidak merusak kulit tersebut. Jika terjadi kesalahan dalam penyadapan, maka produksi karet akan berkurang dan sebaliknya. Untuk memperoleh hasil sadap yang baik, penyadapan harus mengikuti aturan tertentu agar diperoleh hasil yang tinggi, menguntungkan, serta berkesinambungan dengan tetap memperhatiakan faktor kesehatan tanaman.

Tanda estimasi yang dimiliki oleh variabel teknik penyadapan bernilai positif. Hal ini menjelaskan bahwa dengan meningkatkan teknik penyadapan sesuai anjuran maka akan meningkatkan produktivitas karet atau sebaliknya. Elastisitas variabel teknik penyadapan terhadap produktivitas karet dapat dikatakan inelastis, yaitu sebesar 0,096. Artinya apabila teknik penyadapan sesuai anjuran bertambah sebesar satu persen (1\%), maka akan meningkatkan produktivitas karet sebesar 0,096 persen, dengan syarat cateris paribus.

Berdasarkan analisis dengan metode Cobb-Douglas, didapat bahwa nilai sig. untuk kondisi kebun (D3) sebesar 0,002 (tabel 2) lebih kecil dibandingkan dengan nilai $\alpha$ $=(0,05)$, dan diketahui bahwa t-hitung lebih besar dari t-tabel $(3,162>1,988)$. Hal ini menunjukkan bahwa variabel dugaan yakni kondisi kebun terbukti secara signifikan mempengaruhi produktivitas perkebunan karet di Kecamatan Singkut. Hasil analisis ini sependapat dengan soekartawi (1898) yang menyatakan Pemeliharaan tanaman dapat terwujud baik dengan memperhatikan penggunaan bibit unggul, teknologi pengambilan hasil, waktu pemanenan, kondisi kebun (teratur atau tidak teratur), dan lain sebagainya. Pendayagunaan sumber dan hubungan-hubungan yang terjalin baik buruknya atau gagal 
dan berhasilnya sangat tergantung pada manusia atau petani yang melangsungkan produksi tersebut, apakah selalu bergairah, rajin, giat, ulet, serta selalu berkeinginan untuk meningkatkan perolehan atau produksinya.

Tanda estimasi yang dimiliki oleh variabel kondisi kebun bernilai positif. Hal ini menjelaskan bahwa dengan semakin bersih dan teraturnya kondisi kebun maka akan meningkatkan produktivitas karet atau sebaliknya. Elastisitas variabel kondisi kebun terhadap produktivitas karet dapat dikatakan inelastis, yaitu sebesar 0,130. Artinya apabila kebersihan lahan dan keteraturan lahan bertambah sebesar satu persen (1\%), maka akan meningkatkan produktivitas karet sebesar 0,130 persen, dengan syarat cateris paribus.

\section{KESIMPULAN}

Dari hasil penelitian dengan menggunakan metode Cobb-douglas secara keseluruhan (uji f) estimasi dari model faktor-faktor yang mempengaruhi produktivitas karet rakyat memberikan hasil yang signifikan. Faktor-faktor tersebut mampu menjelaskan produktivitas karet rakyat di Kecamatan Singkut sebesar 82,3 persen. Secara parsial (uji $t$ ), luas lahan, jumlah tenaga kerja, jenis bibit, teknik penyadapan dan kondisi kebun berpengaruh nyata terhadap produktivitas karet rakyat di Kecamatan Singkut.

\section{UCAPAN TERIMAKASIH}

Terima kasih kepada Bapak Camat Kecamatan Singkut, Kepala BP3K Kecamatan Singkut, Bapak Kepala Desa Bukit Murau, Siliwangi, Simpang Nibung serta masyarakat yang bersedia memberikan keterangan untuk keperluan data penelitian. Terima kasih kepada staf Dinas Perkebunan Provinsi Jambi dan Badan Pusat Statistik Provinsi Jambi yang telah memberikan literature berupa data sekunder.

\section{DAFTAR PUSTAKA}

Anggara, A. 2008. Agribisnis Tanaman Perkebunan. Penebar Swadaya : Jakarta.

Badan Pusat Statistik Jambi. 2009. Jambi Dalam Angka. Badan Pusat Statistik Provinsi Jambi : Jambi.

Damanik. S, M. Syakir, Made Tasma, Siswanto. 2010. Budidaya Dan Pasca Panen Karet. Pusat Penelitian Dan Pengembangan Perkebunan: Bogor.

Dinas Perkebunan Provinsi Jambi. 2011. Dinas Perkebunan Provinsi Jambi Tahun 2011. Dinas Perkebunan Provinsi Jambi. Jambi.

Gujarati, Damodar, 2003. Basic Econometrics, Fourth Edition, Mcgraw Hill, New York. . 2006. Dasar-dasar Ekonometrika Edisi Ketiga. Erlangga : Jakarta

Piyatno, Dwi. 2004. Paham Analisis Statistik Data Dengan SPSS. Mediakom : Yogyakarta.

Polman, J.S. 2000. Analisa Faktor-Faktor Yang Mempengaruhi Produksi Karet Rakyat Di Kecamatan Dolok Merawan, Kabupaten Deli Serdang. (Diunduh dari http://repository.usu.ac.id) ) Diakses Pada Tanggal 10 Mei 2013.

Riduan. 2007. Pengantar Statistika Untuk Penelitian Pendidikan, Sosial, Ekonomi Dan Bisnis. Alfabeta : Bandung.

Soekartawi, 1989. Prinsip Ekonomi Pertanian. PT. Raja Grafindo Persada : Jakarta.

Tim Penulis PS. 2012. Panduan Lengkap Karet. Edisi Keempat. Penebar Swadaya : Jakarta.

Usman, Rianse dan Abdi. 2009. Metodologi Penelitian Sosial dan Ekonomi Teori dan Aplikasi. CV Alfabeta: Bandung.

Wijawa, Sukma R. 2012. Praktek Akuntansi Manajemen pada Perusahaan di Kawasan Industri Batam. Thesis Universitas Andalas. Padang. 